\title{
Impacts of human alteration of the nitrogen cycle in the US on radiative forcing
}

\author{
Robert W. Pinder • Neil D. Bettez • Gordon B. Bonan • \\ Tara L. Greaver • William R. Wieder • William H. Schlesinger • \\ Eric A. Davidson
}

Received: 23 May 2012/ Accepted: 23 August 2012/Published online: 9 September 2012

(C) The Author(s) 2012. This article is published with open access at Springerlink.com

\begin{abstract}
Nitrogen cycling processes affect radiative forcing directly through emissions of nitrous oxide $\left(\mathrm{N}_{2} \mathrm{O}\right)$ and indirectly because emissions of nitrogen oxide $\left(\mathrm{NO}_{x}\right)$ and ammonia $\left(\mathrm{NH}_{3}\right)$ affect atmospheric concentrations of methane $\left(\mathrm{CH}_{4}\right)$, carbon dioxide $\left(\mathrm{CO}_{2}\right)$, water vapor $\left(\mathrm{H}_{2} \mathrm{O}\right)$, ozone $\left(\mathrm{O}_{3}\right)$ and aerosols. The emissions of $\mathrm{N}_{2} \mathrm{O}$ are mostly from agriculture and they contribute to warming on both short and long time scales. The effects of $\mathrm{NO}_{x}$ and $\mathrm{NH}_{3}$ on $\mathrm{CH}_{4}, \mathrm{O}_{3}$, and aerosols are complex, and quantification of these effects is difficult. However, the net result on time scales of decades is likely one of cooling, which becomes less significant on longer time scales. Deposition of $\mathrm{N}$ onto ecosystems also affects sources and sinks of $\mathrm{N}_{2} \mathrm{O}, \mathrm{CH}_{4}$, and $\mathrm{CO}_{2}$, but the dominant effect is changes in carbon (C) stocks. Primary productivity in most temperate ecosystems is
\end{abstract}

R. W. Pinder $(\bowtie) \cdot$ T. L. Greaver

US Environmental Protection Agency, Office of Research and Development, Durham, NC 27711, USA

e-mail: pinder.rob@epa.gov

T. L. Greaver

e-mail: greaver.tara@epa.gov

N. D. Bettez - W. H. Schlesinger

Cary Institute of Ecosystem Studies, Millbrook,

NY 12545, USA

e-mail: bettezn@caryinstitute.org

W. H. Schlesinger

e-mail: schlesingerw@caryinstitute.org limited by $\mathrm{N}$, so inputs from atmospheric deposition tend to stimulate plant growth and plant litter production, leading in some cases to significant $C$ sequestration in biomass and soils. The literature reviewed here indicates a range of estimates spanning 20-70 kg C sequestered per $\mathrm{kg} \mathrm{N}$ deposited in forests, which are the dominant $\mathrm{C}$ sinks. Most of the sequestration occurs in aboveground forest biomass, with less consistency and lower rates reported for $\mathrm{C}$ sequestration in soils. The permanency of the forest biomass sink is uncertain, but data for the fate of forest products in the US indicate that only a small fraction of enhanced forest biomass $\mathrm{C}$ is sequestered in long-term harvest products or in unmanaged forests. The net effect of all of these $\mathrm{N}$ cycle processes on radiative forcing in the US is probably a modest cooling effect for a 20 -year time frame, although the uncertainty of this estimate

G. B. Bonan

National Center for Atmospheric Research, Boulder, CO 80305, USA

e-mail: bonan@ucar.edu

W. R. Wieder

National Center for Atmospheric Research, Boulder, CO 80307, USA

e-mail: wwieder@ucar.edu

E. A. Davidson

Woods Hole Research Center, Falmouth,

MA 02540, USA

e-mail: edavidson@whrc.org 
includes zero net effect, and a modest warming for a 100-year time frame. We know that $\mathrm{N}$-cycling processes are important and that biotic feedbacks to climate change are unlikely to be properly modeled or assessed without including $\mathrm{C}-\mathrm{N}$ interactions. However, due to the complexity of biological processes involving $\mathrm{C}-\mathrm{N}$-climate interactions, biogeochemical models are still poorly constrained with respect to ecosystem responses to impacts of $\mathrm{N}$ deposition and climate change. Only recently have N-cycling processes been incorporated into Earth system models for $\mathrm{C}-\mathrm{N}$ interactions. The robustness of these models remains to be demonstrated. Much work remains for improving their representation in models used to simulate climate forcing scenarios.

Keywords Climate change - Reactive nitrogen Carbon cycle $\cdot$ Atmospheric chemistry

\section{Introduction}

Reactive nitrogen $(\mathrm{Nr})$ emissions alter the climate in many ways, and the importance of the nitrogen $(\mathrm{N})$ cycle in regulating climate is gaining increasing attention. Excess $\mathrm{N}$ in terrestrial systems can change the uptake and emission of the three most important anthropogenic greenhouse gases: carbon dioxide $\left(\mathrm{CO}_{2}\right)$, methane $\left(\mathrm{CH}_{4}\right)$, and nitrous oxide $\left(\mathrm{N}_{2} \mathrm{O}\right)$. Many experiments have demonstrated substantial $\mathrm{N}$ limitations of $\mathrm{CO}_{2}$ uptake on land. Therefore, owing to its scarcity, $\mathrm{N}$ is a chief player in climate change and the fate of anthropogenic $\mathrm{CO}_{2}$ emissions. In addition, $\mathrm{Nr}$ is a substrate for $\mathrm{N}_{2} \mathrm{O}$ production by nitrifying and denitrifying bacteria in soils, sediments, and water bodies. Microbial production and consumption of $\mathrm{CH}_{4}$ is also affected by $\mathrm{N}$. In the atmosphere, $\mathrm{Nr}$ alters atmospheric chemistry and affects the production and lifetimes of greenhouse gases such as ozone $\left(\mathrm{O}_{3}\right)$ and $\mathrm{CH}_{4}$, and also leads to the formation of aerosols, which, in turn, affect regional and global climate. This article provides an overview on the impacts of $\mathrm{Nr}$ on radiative forcing, paying particular attention to the specific interaction between the $\mathrm{N}$ and carbon (C) cycles. We present evidence from field studies, metaanalyses, and models of biogeochemical processes within earth system models.

\section{Radiative impacts of reactive nitrogen}

The most direct effect of $\mathrm{N}$ on climate is through $\mathrm{N}_{2} \mathrm{O}$ production, the third most important anthropogenic greenhouse gas, contributing $6 \%$ of total humaninduced global warming. It has about 300 times the per-molecule warming potential of $\mathrm{CO}_{2}$ and it is longlived in the atmospheric (a "mean residence time" of more than 110 years) (Forster et al. 2007). The concentration of $\mathrm{N}_{2} \mathrm{O}$ in Earth's atmosphere is derived from a variety of sources, mainly from the activity of nitrifying and denitrifying bacteria in soils, sediments, and water bodies. Globally, natural ecosystems release about $10 \mathrm{Tg} \mathrm{N}_{2} \mathrm{O}-\mathrm{N}$ year $^{-1}$, and anthropogenic sources sum to about $7 \mathrm{Tg} \mathrm{N}_{2} \mathrm{O}-\mathrm{N}$ year ${ }^{-1}$, although one recent study has reported a lower natural contribution (Zhuang et al. 2012). Anthropogenic sources are dominated by the widespread use and subsequent microbial processing of fertilizer in agricultural soils (Forster et al. 2007). Atmospheric concentrations of $\mathrm{N}_{2} \mathrm{O}$ have increased rapidly since the industrial revolution, as livestock herds increased globally and as use of synthetic-N fertilizers increased after WWII (Davidson 2009). The natural sink for $\mathrm{N}_{2} \mathrm{O}$ in soils is small (Syakila and Kroeze 2011; Van Groenigen et al. 2011). The current rate of increase in the concentration of $\mathrm{N}_{2} \mathrm{O}$ is about $0.3 \%$ year $^{-1}$, equivalent to the accumulation of $4 \mathrm{Tg} \mathrm{N} \mathrm{N}_{2} \mathrm{O}-\mathrm{N}$ year ${ }^{-1}$ in Earth's atmosphere. Global emissions of $\mathrm{N}_{2} \mathrm{O}$ are likely to increase as fertilizers are used to boost agricultural productivity.

The US EPA estimates that agricultural activities in the US are directly or indirectly responsible for emissions of about 0.48 million tons of $\mathrm{N}_{2} \mathrm{O}-\mathrm{N}$ year ${ }^{-1}$ (United States Environmental Protection Agency Office of Atmospheric Programs, 2011), which is about $80 \%$ of total US $\mathrm{N}_{2} \mathrm{O}$ production (the remainder from energy and industrial sources) and about $10 \%$ of the global $\mathrm{N}_{2} \mathrm{O}$ emissions from agriculture. Several mitigation options exist to reduce the emissions of $\mathrm{N}_{2} \mathrm{O}$ from agricultural soils (Davidson et al. 2012), and are addressed in more detail in Robertson et al. (this issue). Associated emissions of $\mathrm{N}_{2} \mathrm{O}$ are estimated to negate much of the $\mathrm{CO}_{2}$ mitigation effect from $C$ sequestration in soils (e.g., Schlesinger 2010) or from biofuel production using fertilized crops such as corn (Melillo et al. 2009).

While not a greenhouse gas directly, nitrogen oxides $\left(\mathrm{NO}_{x}\right)$ are often a limiting factor in the 
Table 1 Change in ozone and methane radiative forcing $\left(\mathrm{mW} \mathrm{m}^{-2}\right)$ due to reactive nitrogen (per $\mathrm{Tg}$ $\mathrm{N}$ ), as calculated in global, regional, and sourcespecific sensitivity studies

\begin{tabular}{llll}
\hline Source & Region/sector & $\mathrm{NO}_{x} \rightarrow$ ozone & $\mathrm{NO}_{x} \rightarrow$ methane \\
\hline Derwent et al. (2008) & Global & +1.0 & -2.4 \\
Naik et al. (2005) & North America & +0.088 & -1.7 \\
Fry et al. (2012) & North America & +2.2 & -2.7 \\
Berntsen et al. (2005) & Europe & +2.0 & -1.9 \\
Wild et al. (2001) & Mid-latitudes & +1.1 & -1.9 \\
West et al. (2007) & Anthropogenic & +2.9 & -3.7 \\
Stevenson et al. (2004) & Aircraft & +1.5 & -13.8 \\
Khler et al. (2008) & Aircraft & +28 & -28 \\
Eyring et al. (2007) & Shipping & +1.3 & -4.5 \\
Endresen et al. (2003) & Shipping & +3.8 & -7.7 \\
Fuglestvedt et al. (2008) & Shipping & +5.3 & -7.6 \\
\hline
\end{tabular}

production of $\mathrm{O}_{3}$ in the troposphere (the lower atmosphere), which acts as a potent greenhouse gas (Derwent et al. 2008). Nitrogen oxide (NO) reacts with radicals that donate an oxygen atom and convert the $\mathrm{NO}$ to nitrogen dioxide $\left(\mathrm{NO}_{2}\right)$. In sunlight, $\mathrm{NO}_{2}$ can give up one of its oxygen atoms as it is converted back to NO by photolysis. The extra atomic oxygen reacts with the molecular oxygen $\left(\mathrm{O}_{2}\right)$, which is abundant in the lower atmosphere, and creates $\mathrm{O}_{3}$. In the short-term, $\mathrm{NO}_{x}$ emissions contribute to warming by enhancing tropospheric $\mathrm{O}_{3}$ concentrations. Furthermore, the short-term increase in $\mathrm{O}_{3}$ due to $\mathrm{NO}_{x}$ can impact climate indirectly, by damaging photosynthesis and plant $\mathrm{CO}_{2}$ uptake by as much as $20 \%$, leading to a reduction of atmospheric $\mathrm{CO}_{2}$ sequestration by the plant biomass and resulting in more $\mathrm{CO}_{2}$-driven warming (Felzer et al. 2004; Ollinger et al. 1997; Sitch et al. 2007). Carbon storage and $\mathrm{Nr}$ are discussed in more detail in the next section.

Another indirect effect of $\mathrm{NO}_{x}$ is through its effect on $\mathrm{CH}_{4}$, which is the second-most important greenhouse gas, contributing $15 \%$ of total human-induced global warming. With an atmospheric lifetime of 12 years, $\mathrm{CH}_{4}$ has roughly 27 times the per-molecule warming potential of $\mathrm{CO}_{2}$ (Boucher et al. 2009). The largest removal process of $\mathrm{CH}_{4}$ is oxidation by the hydroxyl radical $(\mathrm{OH})$, accounting for $88 \%$ of the total sink. Emissions of $\mathrm{NO}_{x}$ can increase atmospheric $\mathrm{OH}$ and accordingly, decrease $\mathrm{CH}_{4}$ concentrations (Boucher et al. 2009). An additional feedback is that the by-products of $\mathrm{CH}_{4}$ oxidation include radicals that can convert $\mathrm{NO}$ to $\mathrm{NO}_{2}$. Through this mechanism, $\mathrm{CH}_{4}$ is also an important contributor to ozone formation (Fiore et al. 2002). Hence, in addition to increasing $\mathrm{O}_{3}$ on daily time scales, $\mathrm{NO}_{x}$ can lead to decreases in $\mathrm{O}_{3}$ concentration on a decadal time scale, because it causes an increase in $\mathrm{OH}$ radical concentration, which decreases $\mathrm{CH}_{4}$ concentration, which decreases $\mathrm{NO}_{2}$ formation, which decreases $\mathrm{O}_{3}$ formation.

Because $\mathrm{NO}_{x}$ can both increase and decrease ozone production, the net result of these competing effects strongly depends on where the $\mathrm{NO}_{x}$ emissions occur (Berntsen et al. 2005; Collins et al. 2010; Fry et al. 2012; Naik et al. 2005). However, the net impact of $\mathrm{NO}_{x}$ on atmospheric chemistry is likely to be cooling, by (i) decreasing the $\mathrm{CH}_{4}$ concentration, and (ii) decreasing $\mathrm{O}_{3}$ formation due to lower $\mathrm{CH}_{4}$ concentrations (Fuglestvedt et al. 2010; Wild et al. 2001). Both global, regional, and emission sector-based estimates of the impact of $\mathrm{NO}_{x}$ on $\mathrm{CH}_{4}$ and $\mathrm{O}_{3}$ radiative forcing are listed in Table 1.

In addition to altering radiative forcing from $\mathrm{CH}_{4}$ and $\mathrm{O}_{3}$, both $\mathrm{NO}_{x}$ and ammonia $\left(\mathrm{NH}_{3}\right)$ also react with other atmospheric constituents to form fine particles called aerosols. Aerosols are powerful cooling agents, both directly by scattering or absorbing light, and indirectly, by affecting cloud formation and lifetime (Forster et al. 2007). Ammonium sulfate $\left(\left(\mathrm{NH}_{4}\right)_{2} \mathrm{SO}_{4}\right)$, ammonium nitrate $\left(\mathrm{NH}_{4} \mathrm{NO}_{3}\right)$, and organic aerosols are especially important in these processes. Because $\mathrm{NO}_{x}$ influences the rate of oxidation in the atmosphere, it impacts the formation of sulfate and organic aerosols (Shindell et al. 2009). Ammonia $\left(\mathrm{NH}_{3}\right)$ is the most important atmospheric base, and by neutralizing sulfate and nitrate $\left(\mathrm{NO}_{3}^{-}\right)$, it can enhance the formation of new particles and can condense onto existing acidic particles. Both $\mathrm{NO}_{x}$ and 
Table 2 Change ammonium nitrate $\left(\mathrm{NH}_{4} \mathrm{NO}_{3}\right)$ radiative forcing ( $\mathrm{W} \mathrm{m}^{-2}$ ) due to global anthropogenic emissions, as calculated in global climate modeling studies

\begin{tabular}{lll}
\hline Source & $\mathrm{W} \mathrm{m}^{-2}$ & Type of radiative forcing \\
\hline Forster et al. (2007, Table 2.13) & $-0.10 \pm 0.10$ & $\mathrm{NH}_{4} \mathrm{NO}_{3}$ aerosol direct effect \\
Adams et al. (2001) & -0.19 & $\mathrm{NH}_{4} \mathrm{NO}_{3}$ aerosol direct effect \\
Liao and Seinfeld (2005) & -0.16 & $\mathrm{NH}_{4} \mathrm{NO}_{3}$ aerosol direct effect \\
Bauer et al. (2007) & -0.06 & $\mathrm{NH}_{4} \mathrm{NO}_{3}$ aerosol direct effect \\
Myhre et al. (2009) & -0.023 & $\mathrm{NH}_{4} \mathrm{NO}_{3}$ aerosol direct effect \\
Shindell et al. (2009) & -0.11 & $\mathrm{NH}_{4} \mathrm{NO}_{3}$ aerosol direct effect \\
Xu and Penner (2012) & -0.12 & $\mathrm{NH}_{4} \mathrm{NO}_{3}$ aerosol direct effect \\
Xu and Penner (2012) & -0.09 & Effect of nitric acid gas and $\mathrm{NH}_{4} \mathrm{NO}_{3}$ \\
& & aerosol on cloud droplets \\
\hline
\end{tabular}

plant growth and $\mathrm{C}$ storage is described in the next section.

\section{$\mathrm{N}$ effects on carbon storage}

Atmospheric deposition of $\mathrm{Nr}$ affects terrestrial $\mathrm{C}$ sinks by affecting two key processes. First, inputs of $\mathrm{Nr}$ from atmospheric deposition can enhance plant growth rates because of the fundamental constraint of $\mathrm{N}$ availability on plant productivity and $\mathrm{CO}_{2}$ uptake into plant biomass. Second, decomposition is affected by altering $\mathrm{Nr}$ availability which slows decomposition of plant litter and soil organic matter in many, but not all, forest types. Excess $\mathrm{N}$ can also impact $\mathrm{C}$ cycling in coastal and marine ecosystems; this is discussed in Baron et al. (this issue).

$\mathrm{N}$ effects on plant growth rates

It is well established that net primary production (NPP) is limited by $\mathrm{N}$ availability in many terrestrial ecosystems (LeBauer and Treseder 2008), due to the fact that experimental or fertilizer $\mathrm{N}$ additions typically increase $\mathrm{C}$ capture and storage. A meta-analysis of $126 \mathrm{~N}$ addition experiments evaluated $\mathrm{N}$ limitation of aboveground net primary productivity (ANPP) in terrestrial ecosystems by comparing above-ground plant growth in fertilized to control plots (LeBauer and Treseder 2008). ANPP was calculated by multiple methods, including allometric biomass increment plus litterfall, basal area increment, diameter increment, annual litterfall, and allometric volume increment. The results showed that most ecosystems are $\mathrm{N}$ limited with an average $29 \%$ growth response to $\mathrm{N}$ additions. The response was significant within temperate forests, tropical forests, temperate grasslands, tropical 
Table 3 Current mean estimates of $\mathrm{dC} / \mathrm{dN}$ ratio for forest ecosystems in North America

\begin{tabular}{|c|c|c|c|c|c|}
\hline \multirow[t]{2}{*}{ Approach } & \multicolumn{3}{|c|}{$\begin{array}{l}\text { Carbon sequestration } \\
{\left[\mathrm{kg} \mathrm{C} \text { year }^{-1}\right.} \\
\left.\left(\mathrm{kg} \mathrm{N} \mathrm{year}^{-1}\right)^{-1}\right]\end{array}$} & \multirow[b]{2}{*}{ Scale of application } & \multirow[b]{2}{*}{ Authors } \\
\hline & $\begin{array}{l}\text { Above } \\
\text { ground }\end{array}$ & $\begin{array}{l}\text { Below } \\
\text { ground }\end{array}$ & Total & & \\
\hline $\begin{array}{l}\text { Empirical field data; correlation between NEP } \\
\text { and total } \mathrm{N} \text { deposition }{ }^{\mathrm{a}}\end{array}$ & - & - & $68-177$ & $\begin{array}{l}\text { Chronosequences in boreal } \\
\text { and temperate forests of } \\
\text { Eurasia and North America }\end{array}$ & $\begin{array}{l}\text { Magnani et al. (2007) } \\
\text { as re-evaluated by } \\
\text { Sutton et al. }(2008)^{\mathrm{c}}\end{array}$ \\
\hline $\begin{array}{l}\text { Meta-analysis of } 9 \text { U.S. studies measuring the } \\
\text { effects of N addition on total ecosystem } \\
\text { carbon (EC); only included studies of which } \\
\text { control and treatment sites experienced the } \\
\text { same climatic, soil and vegetation conditions }\end{array}$ & - & - & 24.5 & U.S. forests & $\begin{array}{l}\text { Liu and Greaver } \\
(2009)^{c}\end{array}$ \\
\hline $\begin{array}{l}\text { Modeled values of } \mathrm{N} \text { stimulation of above } \\
\text { ground } \mathrm{C} \text { accumulation based on } \\
\text { measurements of tree growth along an } \mathrm{N} \\
\text { deposition gradient }{ }^{\mathrm{b}} \text {; below ground values } \\
\text { calculated using a biometric relationship }\end{array}$ & 61 & 12 & 73 & $\begin{array}{l}24 \text { common tree species } \\
\text { occurring in Northeastern } \\
\text { forest in the US }\end{array}$ & Thomas et al. $(2010)^{\mathrm{c}}$ \\
\hline $\begin{array}{l}\text { Synthesis of } 14 \text { forest studies (conducted from } \\
1983 \text { to 2010) including observed } \\
\text { measurements and modeled values }\end{array}$ & 25 & 15 & 41 & $\begin{array}{l}\text { Mostly European sites, } \\
\text { several North American } \\
\text { sites }\end{array}$ & $\begin{array}{l}\text { Butterbach-Bahl et al. } \\
\text { (2011) }\end{array}$ \\
\hline
\end{tabular}

grasslands, wetlands, and tundra, but not deserts (LeBauer and Treseder 2008). The majority of these estimates were based on data from forest ecosystems in northern latitudes, whereas tropical areas and other ecosystem types were not well represented (LeBauer and Treseder, 2008).

While increasing $\mathrm{N}$ availability can stimulate plant growth, estimates of this stimulation show greater variation. For example, in a recent synthesis by ButterbachBahl et al. (2011), the average increase in above ground $\mathrm{C}$ sequestration per unit of $\mathrm{N}$ addition is $25 \mathrm{~kg} \mathrm{C} \mathrm{kg}^{-1} \mathrm{~N}$ (Table 3). For eastern US forests, Thomas et al. (2010) estimated an above-ground sink of $61 \mathrm{~kg} \mathrm{C} \mathrm{kg}^{-1} \mathrm{~N}$. The magnitude of growth stimulation is likely greatest in regions of moderate $\mathrm{Nr}$ deposition and slower or even leading to enhanced mortality in regions of highest $\mathrm{Nr}$ deposition, due to nutrient imbalances or acidification (Aber et al. 1998). At present, most US ecosystems are probably in the former category, although some high elevation ecosystems in the eastern US may be in the latter category (Pardo et al. 2011). Finally, some ecosystems are also limited by phosphorous $(\mathrm{P})$. When both $\mathrm{N}$ and $\mathrm{P}$ are enhanced, the impact of $\mathrm{N}$ can be substantially larger (Elser et al. 2007; Harpole et al. 2011).
The addition of $\mathrm{N}$ has also been shown to increase foliar $\mathrm{N}$ concentration (Xia and Wan 2008), which often results in higher photosynthetic rates, but not at high levels of chronic $\mathrm{N}$ addition (Bauer et al. 2004). The de-coupling of a photosynthetic-N relationship was observed in numerous chronic $\mathrm{N}$-addition studies, mainly because the excess $\mathrm{N}$ was invested in amino acids rather than enzymes and proteins associated with the photosynthetic process (Bauer et al. 2004). Foliar $\mathrm{N}$ may also increase the albedo of the canopy, enhancing the reflectivity of the Earth's surface, and hence contribute to cooling (Hollinger et al. 2010; Ollinger et al. 2008).

It is important to note that the potential for $\mathrm{N}$ addition to increase above-ground $\mathrm{C}$ biomass is limited in part because only a small portion of added $\mathrm{N}$ is actually taken up by vegetation, and thus only a small portion of $\mathrm{N}$ contributes to $\mathrm{C}$ capture by trees (Nadelhoffer et al. 1999). Recovery in tree biomass (e.g., foliage, woody tissue, and fine roots) of $\mathrm{N}$ that was experimentally added to forests has been estimated to range between 7-16\% (Nadelhoffer et al. 2004) and 0-45 \% (Schlesinger 2009). Nitrogen may be immobilized in the soil, leached out before 
biological assimilation, or, upon the addition of $\mathrm{N}$, another factor may become limiting to growth (e.g., water or other nutrients).

$\mathrm{N}$ effects on carbon storage in soils

While $\mathrm{N}$ deposition may stimulate productivity and facilitate significant $\mathrm{C}$ storage aboveground (LeBauer and Treseder 2008; Xia and Wan 2008), similar trends have not been as clearly observed in soils. With greater productivity, $\mathrm{N}$ addition generally increases aboveground litter inputs (LeBauer and Treseder 2008; Liu and Greaver 2010; Xia and Wan, 2008), and improves the chemical quality of that litter (i.e., lower lignin: $\mathrm{N}$ ratios and greater labile $\mathrm{C}$ inputs to surface soils; (Berg and Laskowski 2006). In contrast, $\mathrm{N}$ addition decreases fine root production, root respiration (Janssens et al. 2010), and mycorrhizal abundance (Treseder 2004). Although these patterns are not consistent across meta-analyses (Liu and Greaver 2010), they support the idea that higher plant productivity associated with $\mathrm{N}$ deposition shifts litter production aboveground as plant investment for nutrient acquisition declines (Aerts and Chapin 2000).

The biochemistry of litter inputs, and especially litter lignin content, influences the effect of $\mathrm{N}$ addition on soil C storage. For example, Waldrop et al. (2004) report significant soil $\mathrm{C}$ losses with $\mathrm{N}$ addition in a sugar maple forest delivering high quality litter, and significant soil $\mathrm{C}$ gains with $\mathrm{N}$ addition in a nearby oak-dominated forest with lower quality litter. Similarly, root lignin content affects soil $\mathrm{C}$ storage in grassland ecosystems receiving elevated $\mathrm{CO}_{2}$ and $\mathrm{N}$ addition (Dijkstra et al. 2004). Concurrently, $\mathrm{N}$ addition is also known to influence changes in plant species composition (Clark and Tilman 2008). The extent to which climate, $\mathrm{N}$ addition, and their interactions may drive changes in species composition that simultaneously alter the quantity and quality of litter inputs have been little explored in the literature (but see Aerts and Bobbink 1999).

Nitrogen deposition elicits a host of microbial responses that influence organic matter decomposition and, ultimately, influence soil $\mathrm{C}$ storage. Microbial responses to $\mathrm{N}$ addition include: changes in relative enzyme activity, microbial substrate use, and microbial community composition (Cusack et al. 2011; Sinsabaugh and Moorhead 1994). Notably, N addition accelerates the decomposition of high quality (low lignin) litter by stimulating cellulose degradation, which is typically N limited (Berg and Matzner 1997; Carreiro et al. 2000; Fog 1988; Frey et al. 2004, Saiya-Cork et al. 2002; Sinsabaugh et al. 2002). In contrast, $\mathrm{N}$ addition significantly slows decomposition of low quality (high lignin) litter because of decreases in phenol oxidase activity, which reduces rates of lignin degradation (Fog 1988; Hammel 1997; Sinsabaugh et al. 2002). This divergent pattern based on litter quality has significant implications for soil $\mathrm{C}$ storage in systems receiving $\mathrm{N}$ deposition. In some systems, decreases in phenol oxidase activity are attributed to declines in fungal biomass, declining fungal: bacterial ratios, and a reduction of Basidiomycetes, or white rot fungi (Carreiro et al. 2000; Fog 1988; Saiya-Cork et al. 2002; Sinsabaugh et al. 2002; Frey et al. 2004). However, fungal declines with $\mathrm{N}$ addition are not ubiquitous in studies reporting changes in microbial community structure (Saiya-Cork et al. 2002; Nemergut et al. 2008; Ramirez et al. 2010). The effects of $\mathrm{N}$ addition on shifts in microbial community structure and function and their influence on litter decomposition are mediated by substrate quality. As a result of these changes in microbial community structure and function, rates of litter decomposition generally slow with $\mathrm{N}$ deposition, although the consistency of these findings is influenced by ambient levels of $\mathrm{N}$ deposition and initial litter chemistry (Fog 1988; Hobbie 2005; Knorr et al. 2005; Janssens et al. 2010). Notably, rates of $\mathrm{N}$-addition more than $5 \mathrm{~kg} \mathrm{ha}^{-1}$ year $^{-1}$ slow litter decomposition, whereas rates of $\mathrm{N}$ deposition less than $5 \mathrm{~kg} \mathrm{ha}^{-1}$ year $^{-1}$ may actually accelerate leaf litter decomposition (Knorr et al. 2005).

Additionally, $\mathrm{N}$ deposition may affect dissolved organic carbon (DOC) export from soil C (Liu and Greaver 2010). Across multiple spatial scales, increasing $\mathrm{N}$ availability increases DOC export from soils (Aitkenhead and McDowell 2000). Mechanisms to explain these patterns are still unresolved, but generally increased DOC losses result from the combination of higher aboveground litterfall, decreased microbial lignin degradation, and soil acidification (Evans et al. 2008; Findlay 2005; Monteith et al. 2007; Sinsabaugh et al. 2004). Although the acceleration of DOC losses by $\mathrm{N}$-addition may have little impact on ecosystem $\mathrm{C}$ storage (Aitkenhead and McDowell 2000), these DOC and $\mathrm{Nr}$ inputs have significant consequences for aquatic ecosystems. 
When combined with observations of higher aboveground productivity and litterfall, one might expect significantly greater soil $\mathrm{C}$ storage in systems exposed to $\mathrm{N}$ addition, but reported rates of accumulation of $\mathrm{C}$ in soils are generally modest. ButterbachBahl et al (2011) estimate that $15 \mathrm{~kg} \mathrm{C}$ are sequestered per $\mathrm{kg} \mathrm{N}$ deposition in forest soils (Table 3). However, meta-analyses show conflicting results for accumulation of soil C with $\mathrm{N}$-addtion (Janssens et al. 2010; Liu and Greaver 2010; Nave et al. 2009). Some of the variation of soil $\mathrm{C}$ accumulation reported in these meta-analyses could result from variation in regional/ ecosystem response to $\mathrm{N}$ addition, or the type, duration, and intensity of $\mathrm{N}$ additions.

\section{$\mathrm{N}$ effects on total ecosystem carbon storage}

It is important to consider both the above and belowground $\mathrm{C}$ pools in terrestrial ecosystems to understand $\mathrm{N}$ effects on total ecosystem $\mathrm{C}$ sequestration. Various approaches, such as modeling, inventory, and static accounting, have been used to estimate the $\mathrm{N}$-induced $\mathrm{C}$ sink for different ecosystems (Holland et al. 1997; Liu and Greaver 2009; Magnani et al. 2007; Thomas et al. 2010). The effect of $\mathrm{N}$ on net $\mathrm{C}$ flux (both above and below ground pools) differs among ecosystems. In general $\mathrm{N}$ addition to grasslands and wetlands does not increase $\mathrm{C}$ storage; however $\mathrm{N}$ stimulates more $\mathrm{C}$ storage in forests (Liu and Greaver 2009). In grasslands and wetlands $\mathrm{N}$ stimulation of ANPP is offset by other C losses in the system. For example, Bragazza et al. (2006) investigated peatlands across a gradient of $\mathrm{N}$ deposition levels and found higher atmospheric $\mathrm{N}$ deposition resulted in higher $\mathrm{C}$ loss by increasing heterotrophic respiration and DOC leaching. Similarly, Mack et al. (2004) found $\mathrm{N}$ fertilization stimulated soil organic carbon (SOC) decomposition more than plant production in a tundra ecosystem, leading to a net loss of ecosystem C. Among terrestrial ecosystems, the response of forests to $\mathrm{N}$ availability has been most intensively studied, but more data are needed to better characterize other types of terrestrial ecosystems.

In forests, a wide range of values have been reported for how much additional $\mathrm{C}$ is expected to be sequestered per unit of $\mathrm{N}$ added. Magnani et al. (2007) published a very high estimate of $725 \mathrm{~kg} \mathrm{C}$ accumulated per $\mathrm{kg} \mathrm{N}$ added $(\mathrm{dC} / \mathrm{dN})$ to boreal and temperate forests. However, this estimate was quickly contested as biologically implausible by Sutton et al. (2008) who reanalyzed the original data and suggested that 68 $\mathrm{dC} / \mathrm{dN}$ was more accurate. Since then, attention has been drawn to the basic stoichiometry constraints for $\mathrm{C}$ sequestration by $\mathrm{N}$ at the ecosystem scale (Schlesinger et al. 2011).

Several studies have evaluated $\mathrm{dC} / \mathrm{dN}$ ratios in US forests and a meta-analysis examined the effect of $\mathrm{N}$ fertilization on ecosystem $\mathrm{C}$ content (EC), defined as the sum of $\mathrm{C}$ content of vegetation, forest floor and soil (Liu and Greaver 2010). To avoid possible confounded variability caused by site conditions, this meta-analysis only included studies where control and treatment sites experienced the same climatic, soil and vegetation conditions. Studies on N effects along a deposition gradient were not included. Results show that while there was a great deal of variation in response, overall $\mathrm{N}$ addition increased EC by $6 \%$ for US forest ecosystems. This study did not find any correlation between the amount of $\mathrm{N}$ addition and the response magnitudes of EC. On average, forest ecosystems sequestered $24.5 \pm 8.7 \mathrm{~kg} \mathrm{C} \mathrm{ha}^{-1}$ year $^{-1}$ per kg N ha ${ }^{-1}$ year $^{-1}$ (Liu and Greaver 2009). Using a different approach, Thomas et al. (2010) examined tree growth rates over an $\mathrm{N}$ deposition gradient in US Northeastern forests. Their results indicate that enhancement of aboveground C storage averaged $61 \mathrm{~kg} \mathrm{C}^{-1}$ year $^{-1}$ per kg increase in $\mathrm{N}$ deposition. When calculating a $\mathrm{dC} / \mathrm{dN}$ response ratio using values of $\mathrm{N}$ deposition, it is very important to consider how $\mathrm{N}$ deposition is calculated and whether all relevant chemical species are included. In Thomas et al. (2010), $\mathrm{N}$ deposition was calculated using estimates of wet $\mathrm{NO}_{3}{ }^{-}$, wet $\mathrm{NH}_{4}{ }^{+}$, dry $\mathrm{HNO}_{3}$ gas and particulate $\mathrm{NH}_{4}{ }^{+}$and $\mathrm{NO}_{3}{ }^{-}$; it did not, however, include other forms of $\mathrm{N}$ deposition, such as dry $\mathrm{NH}_{3}$, $\mathrm{NO}$ and $\mathrm{NO}_{2}$, or organic $\mathrm{N}$. Because all forms of $\mathrm{N}$ deposition were not used in the calculation, above ground $\mathrm{dC} / \mathrm{dN}$ is likely to be over estimated compared to $\mathrm{N}$-addition studies. In addition, when a biometric relationship is applied that assumes below-ground tree biomass represents roughly $20 \%$ of above-ground biomass, then enhancement of total tree $\mathrm{C}$ would increase to $73 \mathrm{~kg} \mathrm{C}^{-1}$ year $^{-1}$ per $\mathrm{kg}$ increase in $\mathrm{N}$ deposition. This approach assumes $\mathrm{dC} / \mathrm{dN}$ in belowground biomass is the same as above ground biomass, which is often not the case (Table 3), and does not include other soil pools that affect $\mathrm{dC} / \mathrm{dN}$. These reasons may partially explain why the Thomas et al. (2010) estimate is larger than the $\mathrm{N}$ addition studies. 
Butterbach-Bahl et al. (2011) recently synthesized and reviewed published $\mathrm{dC} / \mathrm{dN}$ ratios from studies conducted in Europe and North America [not including Liu and Greaver (2009) or Thomas et al. (2010)] and found that average total $\mathrm{C}$ sequestration was $41 \mathrm{~kg}$ $\mathrm{C}$ per kg $\mathrm{N}$ addition in forests. Although more research needs to be done to further refine estimates of $\mathrm{dC} / \mathrm{dN}$ in forests, considering the studies summarized in Table 3 and their caveats, the range of values reported in the literature are between $20-70 \mathrm{~kg} \mathrm{C}^{-1}$ year $^{-1}$ per $\mathrm{kg} \mathrm{N} \mathrm{ha}^{-1}$ year $^{-1}$. Key uncertainties in the sensitivity of ecosystem $\mathrm{C}$ sequestration response to $\mathrm{N}$ addition include the form and manner of $\mathrm{N}$ input, succession status of the forest and prior land-use history (Butterbach-Bahl et al. 2011).

Three factors could decrease rates of $\mathrm{dC} / \mathrm{dN}$ reported for a given forest: $\mathrm{N}$ saturation status, stand age, and availability of other essential nutrients. First, $\mathrm{N}$ will increase NPP of an N-limited system; however $\mathrm{N}$ addition beyond a certain point may lead to decreases in NPP (Aber et al. 1998). Second, several studies have shown that NPP declines with stand age (Gower 2003; Ryan et al. 2004), which could reduce the potential response to $\mathrm{N}$ addition. Furthermore, as NPP decreases due to age, so too will $\mathrm{dC} / \mathrm{dN}$. The relative effect of saturation and stand age is varied-a flux study found evidence of nitrogen enhanced productivity even in an old growth (200-300 years old) forest (Luyssaert et al. 2007).

\section{Biogeochemical models: $\mathbf{C}-\mathrm{N}$ interactions, $\mathrm{C}$ storage, and $\mathbf{N}$ gas emissions}

\section{Modeling $\mathrm{N}$ effects on $\mathrm{C}$ sequestration}

As climate models evolve into models of the behavior of the entire Earth system, they have expanded beyond their hydrometeorological heritage to include biogeochemical cycles and atmospheric chemistry. Early global climate models focused solely on atmospheric physics; later models incorporated the $\mathrm{C}$ cycle in order to include feedback with atmospheric $\mathrm{CO}_{2}$. Coupled $\mathrm{C}$ cycle-climate models include terrestrial and marine $\mathrm{C}$ fluxes so that changes in atmospheric $\mathrm{CO}_{2}$ concentration are simulated in response to anthropogenic $\mathrm{CO}_{2}$ emissions (Denman et al. 2007; Friedlingstein et al. 2006). In these models, rising atmospheric $\mathrm{CO}_{2}$ concentration increases land $\mathrm{C}$ uptake by stimulating plant productivity, and this " $\mathrm{CO}_{2}$ fertilization" is a negative feedback to higher atmospheric $\mathrm{CO}_{2}$ concentration (the concentration- $\mathrm{C}$ feedback). Land $\mathrm{C}$ loss through ecosystem respiration increases with warming in a positive climate feedback (the climate-C feedback). Additionally, warming can enhance productivity (negative feedback) in cold regions, but decrease productivity (positive feedback) in warm regions, where greater evaporative demand dries soil. These predictions for the terrestrial $\mathrm{C}$ cycle are found in Earth system models that do not include $\mathrm{C}-\mathrm{N}$ biogeochemistry. In recent years, some Earth system models have added some representation of the $\mathrm{N}$ cycle as a crucial regulator of C-cycle dynamics and aspects of atmospheric chemistry, but much work is needed to properly incorporate representation of $\mathrm{N}$ cycling processes in climate models. Global biogeochemical models of the terrestrial $\mathrm{C}$ and $\mathrm{N}$ cycles for the Earth build upon a rich heritage of terrestrial ecosystem models (Bonan 2008). They simulate $\mathrm{C}$ and $\mathrm{N}$ flows among various vegetation and soil components, $\mathrm{N}$ inputs for atmospheric deposition and biological $\mathrm{N}$ fixation, and $\mathrm{N}$ losses from denitrification and leaching.

Carbon cycle-climate model simulations of future climate change predict that nitrogen has an important effect on future carbon uptake (Sokolov et al. 2008; Thornton et al. 2009; Zaehle et al. 2010). Limited mineral $\mathrm{N}$ availability restricts the increase in plant productivity from rising $\mathrm{CO}_{2}$ concentration. Conversely, warming increases decomposition of organic material and $\mathrm{N}$ mineralization, stimulating plant productivity. These findings are generally consistent with results from free-air $\mathrm{CO}_{2}$ enrichment experiments and soil warming experiments, though few models have been directly compared with experimental manipulations (Melillo et al. 2011).

As mentioned earlier, because $\mathrm{N}$ availability restricts plant productivity in many ecosystems; $\mathrm{N}$ addition from atmospheric $\mathrm{N}$ deposition can enhance $\mathrm{C}$ storage. Initial studies of the effect of anthropogenic $\mathrm{N}$ deposition on the $\mathrm{C}$ cycle reported that the additional $\mathrm{N}$ in the system increased global terrestrial $\mathrm{C}$ storage from as much as $0.6-1.5 \mathrm{Pg} \mathrm{C}$ year $^{-1}$ (Holland and Lamarque 1997; Townsend et al. 1997) to as little as $0.25 \mathrm{Pg} \mathrm{C}_{\text {year }}{ }^{-1}$ (Nadelhoffer et al. 1999). More recent model simulations support a $C$ sink of about 0.2 $\mathrm{Pg} \mathrm{C}_{\text {year }}{ }^{-1}$ (Bonan and Levis 2010; Jain et al. 2009; Thornton et al. 2009; Zaehle et al. 2011). These models differ in important ecological and 
biogeochemical processes (e.g., how $\mathrm{N}$ affects plant productivity; below-ground $\mathrm{C}-\mathrm{N}$ dynamics; and denitrification) that determine the amount of $\mathrm{N}$ in the system available for plant use and the magnitude of the C sink. Model comparison with results from N-deposition gradient analyses (Thomas et al. 2010) or N-enrichment experiments (Liu and Greaver 2009) are needed to evaluate the model simulations and to identify deficiencies in model parameterizations. Estimates of $\mathrm{N}$-enhanced $\mathrm{C}$ storage, whether derived from observational studies or from models, require knowledge of $\mathrm{N}$ deposition rates. These rates can differ greatly among studies in the magnitude and spatial distribution of the deposition, which makes comparison among studies difficult.

A complete understanding of the effects of increased $\mathrm{N}$ deposition on terrestrial $\mathrm{C}$ storage and radiative forcing requires a multi-disciplinary integration of biogeochemical processes with biogeophysical processes (i.e., energy and water fluxes), and with changes in ecosystem structure and community composition arising from stand dynamics. For example, a more productive forest with higher leaf area index resulting from enhanced $\mathrm{N}$ deposition is likely to decrease surface albedo, warming the climate with a positive radiative forcing and increasing evapotranspiration (Bonan 2008). Increased evapotranspiration locally cools temperature, but can warm global temperature through increased atmospheric water vapor. The net effect of changes in $\mathrm{C}$ storage, surface albedo, and evapotranspiration on radiative forcing is largely unknown for forest ecosystems, and initial estimates of the forcing are quite speculative (Bonan 2008). Another possible biogeophysical forcing is manifested through the effect of foliar $\mathrm{N}$ on leaf-, stem-, and canopy-level traits that alter the overall plant reflectance. Canopy $\mathrm{N}$ concentration is strongly and positively correlated with canopy albedo, suggesting a possibly significant biogeophysical role of $\mathrm{N}$ in the climate system through solar radiation absorption and canopy energy exchange (Hollinger et al. 2010; Ollinger et al. 2008). The long-term sustainability of the $\mathrm{N}$-enhanced $\mathrm{C}$ sink is unclear, and carbon uptake may saturate with future levels of $\mathrm{N}$ deposition. The future potential of $\mathrm{C}$ storage in terrestrial ecosystems depends on trajectories of climate change and land use, which alter community composition and ecosystem structure. Redistribution of plant species in response to climate change alters patterns of $\mathrm{C}$ storage, $\mathrm{N}$ uptake, and $\mathrm{N}$ mineralization (Metcalfe et al. 2011; Pastor and Post 1988). Enhanced C storage in forest ecosystems arising from atmospheric $\mathrm{N}$ deposition becomes less important in a warmer climate where droughts and wildfire are more common. Trajectories of land use (e.g., deforestation, reforestation, and afforestation) driven by socioeconomic needs and policy implementation will also come into play and have competing biogeophysical and biogeochemical impacts on climate. These changes in community composition and ecosystem structure are largely ignored in the current generation of Earth system models, which build on biogeochemical models rather than models of vegetation dynamics.

\section{Modeling $\mathrm{N}$ effects on $\mathrm{N}_{\mathbf{2}} \mathrm{O}$ emissions and other radiative forcing}

The atmospheric chemistry models included in Earth system models allow for additional biogeochemical land-atmosphere interactions such as surface $\mathrm{N}$-gas emission and atmospheric $\mathrm{N}$ deposition (Lamarque et al. 2011). With the addition of $\mathrm{N}$-gas emissions, the models provide surface $\mathrm{N}$ fluxes to atmospheric chemistry models, and can be used to quantify the net radiative forcing due to $\mathrm{Nr}$. This forcing includes the effect of $\mathrm{N}$ on terrestrial $\mathrm{C}$ storage, the direct radiative forcing from $\mathrm{N}_{2} \mathrm{O}$ emissions, and $\mathrm{Nr}$ in the atmosphere and its effects on $\mathrm{CH}_{4}$, tropospheric and stratospheric $\mathrm{O}_{3}$, and secondary aerosols.

Nitrogen losses associated with nitrification and denitrification are poorly represented in the biogeochemical component of Earth system models and present a large uncertainty in global simulations of climate-N interactions (Schlesinger 2009). Dinitrogen gas $\left(\mathrm{N}_{2}\right)$ loss during denitrification is a large term in the global terrestrial $\mathrm{N}$ budget (Galloway et al. 2004; Houlton and Bai2009; Schlesinger 2009), but there is a high degree of uncertainty regarding the amount of $\mathrm{N}_{2}$ lost to the atmosphere (see Houlton et al. this issue). A better understanding and further quantification of ecosystem $\mathrm{N}_{2}$ flux is needed given that this is the best possible outcome for minimizing environmental impacts from excess N. The DayCENT (Del Grosso et al. 2000) and DeNitrification-DeComposition (DNDC) (Li et al. 2000) models are two commonly used approaches to represent nitrification, denitrification, and associated $\mathrm{N}$-gas emissions. In addition, the Environmental Policy Integrated Climate (EPIC) 
(Williams et al. 1996) and Agricultural Policy Environmental EXtender (APEX) (Gassman et al. 2009) simulate these processes for agricultural lands under a range of farming conditions and activities. These models have been evaluated for a wide range of environmental conditions, ecosystem types, and $\mathrm{N}$ inputs (Olander and Haugen-Kozyra 2011), but are mostly applied at the site or regional scale. Global terrestrial biogeochemical models for use with Earth system models may not explicitly simulate denitrification and instead include it as a generic $\mathrm{N}$ loss term (Gerber et al. 2010; Melillo et al. 1993; Wang et al. 2010). Furthermore, some of the current global models represent denitrification as a fraction of mineralization or mineral soil N (Thornton et al. 2009; Yang et al. 2009). Zaehle et al. (2010) developed an advanced process-oriented formulation of nitrification, denitrification, and $\mathrm{N}$-gas emissions based on the DNDC model structure, which observed a likely contribution of $\mathrm{N}$ addition to $\mathrm{C}$ sequestration in forest ecosystems and concurred with ecosystem field studies. Houlton and Bai (2009) used a mass-balance approach constrained by observations of ${ }^{15} \mathrm{~N}:{ }^{14} \mathrm{~N}$ isotope ratios to estimate $\mathrm{NO}, \mathrm{N}_{2} \mathrm{O}$, and $\mathrm{N}_{2}$ emissions globally and regionally. However, the complexity of trace gas biogeochemistry, the fine-scale spatial heterogeneity of trace gas production, and anthropogenic alterations from agricultural practices makes modeling $\mathrm{N}$-gas emissions an uncertain aspect of global Earth system model simulations.

In addition, a key aspect of climate- $\mathrm{N}$ interactions not currently considered by Earth system models is the effect of anthropogenic $\mathrm{N}$ on radiative forcing mediated through changes in atmospheric chemistry. Secondary atmospheric aerosols resulting from emissions of $\mathrm{NO}_{x}$ and $\mathrm{NH}_{3}$ provide a negative radiative forcing that cools climate. None of the currently available Earth system models are able to fully assess these effects, in part because the current generation of global terrestrial $\mathrm{C}-\mathrm{N}$ biogeochemical models used with Earth system models does not represent N-gas emissions and the anthropogenic and environmental drivers of these emissions.

\section{Net effects of $\mathrm{C}-\mathrm{N}$ interactions on radiative forcing}

Reactive $\mathrm{N}$ has numerous effects on climate, including $\mathrm{N}_{2} \mathrm{O}$ emissions, indirect effects on $\mathrm{O}_{3}, \mathrm{CH}_{4}$, and aerosols, and $\mathrm{C}$ sequestration. To compare these impacts, the effects must be converted to a common metric. A recent effort in Europe has led to a continental assessment of the contribution of European emissions of $\mathrm{Nr}$ to instantaneous radiative forcing, expressed as $\mathrm{W} \mathrm{m}^{-2}$ (Butterbach-Bahl et al. 2011). Because aerosols have a large effect on shortterm radiative forcing, it was found that the net effect of cooling from aerosols and $\mathrm{C}$ sequestration outweighed the warming effect of $\mathrm{N}_{2} \mathrm{O}$ emissions across Europe. However, the pathways by which $\mathrm{Nr}$ impacts climate change do not have the same lifetimeaerosols last for only a few weeks, $\mathrm{CH}_{4}$ on the order of a decade, and $\mathrm{N}_{2} \mathrm{O}$ and $\mathrm{CO}_{2}$ persist for more than a century. While radiative forcing is a measure of the instantaneous climate change impact, the long-term climate effects depend heavily on atmospheric longevity (Penner et al. 2010).

An alternative approach is the global temperature potential (GTP), which is a measure of the change in global temperature, after a fixed number of years, due to a $1 \mathrm{~kg}$ pulse of emissions. The GTP can be calculated on a 20-year basis, to identify $\mathrm{Nr}$ impacts likely to change the rate of climate change in the coming decades, as well as a 100-year basis, to understand the long-term magnitude of climate change. To compare across compounds, the GTP is normalized by the change in temperature due to a pulse of $\mathrm{CO}_{2}$ and expressed in common units of $\mathrm{kg}$ $\mathrm{CO}_{2}$ equivalence $\left(\mathrm{CO}_{2} \mathrm{e}\right)$.

The climate change impact of US Nr, on a global temperature potential basis, is presented in Fig. 1. Each bar represents the climate change impact, in units of $\mathrm{Tg} \mathrm{CO}_{2} \mathrm{e}$, due to US $\mathrm{Nr}$ emissions, via the processes listed on the left. The length of the bar denotes the range of uncertainty as estimated by a synthesis of the relevant literature. The impacts from changes in $\mathrm{O}_{3}$, $\mathrm{CH}_{4}$, and aerosols were calculated as the product of US emissions and the GTP of those compounds as calculated by Fuglestvedt et al (2010). For the change in greenhouse gas fluxes due to $\mathrm{N}$ deposition, the $\mathrm{dC} /$ $\mathrm{dN}$ values were multiplied by the anthropogenic $\mathrm{N}$ deposition calculated by the Community Multiscale Air Quality model [CMAQ; Appel et al. (2010)] to each landcover type. A range of 24-65 was used for the $\mathrm{dC} / \mathrm{dN}$ value for forests. The lower value of this range (24) is from Liu and Greaver (2009) and the upper end of this range is from Thomas et al. (2010). The value 65 results from adjusting the Thomas et al. (2010) value upwards to account for below ground 

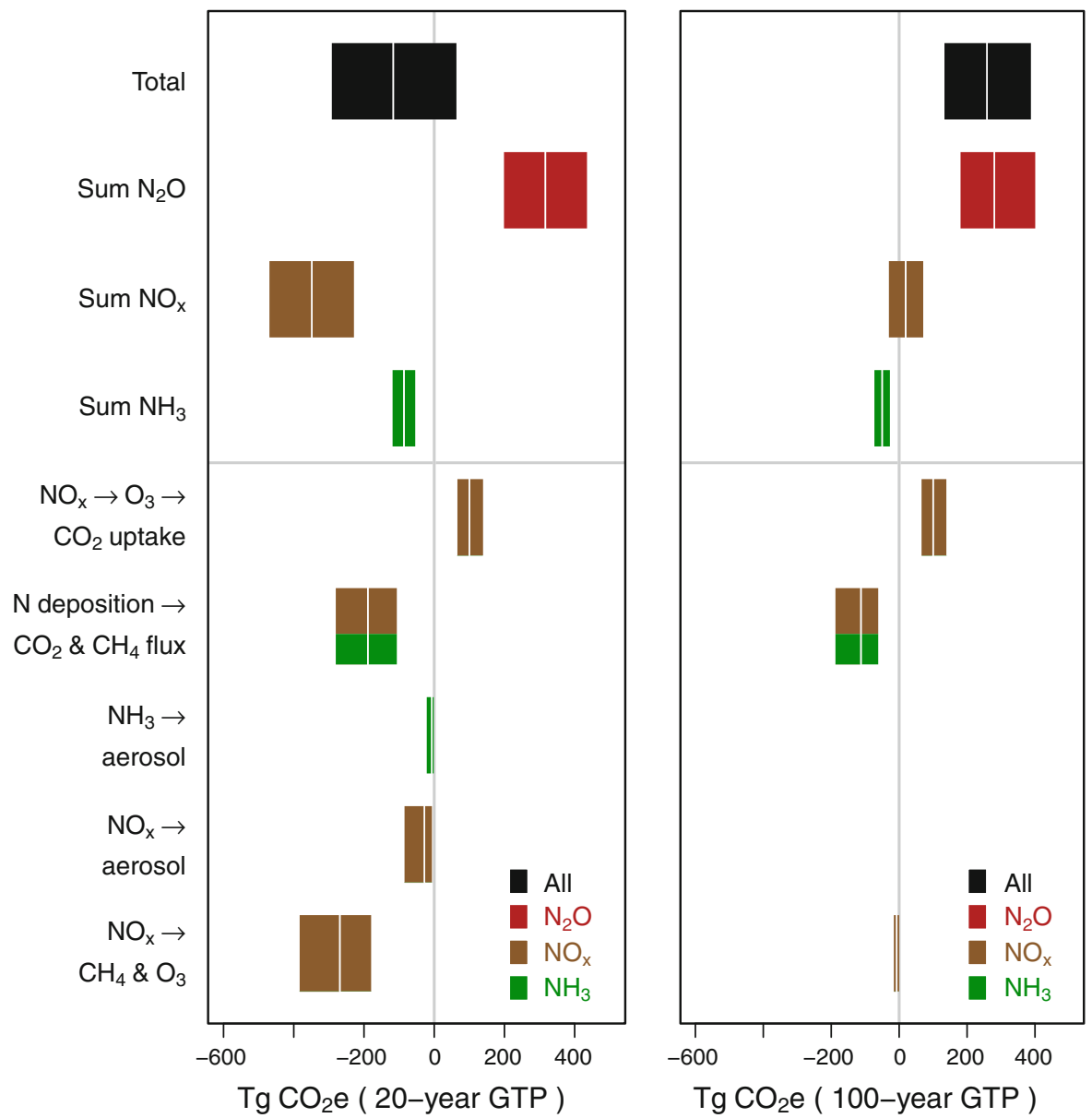

Fig. 1 The climate change impacts of US reactive nitrogen emissions, by chemical species, in common units of equivalent $\mathrm{Tg}$ of $\mathrm{CO}_{2}\left(\mathrm{Tg} \mathrm{CO}_{2 \mathrm{e}}\right)$ on a 20-year and 100-year GTP basis. The width of the bar denotes the uncertainty range; the white line is

biomass and soil $\mathrm{C}$, and downwards, to account for incomplete measurement of N. For other land cover types, the ranges reported in Liu and Greaver (2009) were used. The permanence of enhanced $\mathrm{CO}_{2}$ uptake on a 20-year and 100-year timescale was estimated using forestry management data (Heath et al. 2011). The details of these calculations are described in Pinder et al. (2012).

The relative impact of each aspect of $\mathrm{Nr}$ depends strongly on the time frame of interest. On the left side of Fig. 1, the impacts are compared on a 20-year basis. Here, the change in $\mathrm{O}_{3}, \mathrm{CH}_{4}$, and aerosol concentrations due to $\mathrm{NO}_{x}$ contribute substantially to climate change. But on a 100-year basis, these processes are negligible. Emissions of $\mathrm{NO}_{x}$ in the US contribute to cooling on a 20 -year basis, but have a very little effect the best-estimate; and the color shading shows the relative contribution of $\mathrm{NO}_{x}$ and $\mathrm{NH}_{3}$ emissions to nitrogen deposition (adapted from Pinder et al. 2012)

on a 100-year basis. Overall, the cooling effects (i.e., C sequestration enhanced by $\mathrm{N}$ deposition, increased lifetime of $\mathrm{CH}_{4}$, and greater aerosol burden) are slightly larger than the warming effect of $\mathrm{N}_{2} \mathrm{O}$ on a 20 -year time frame. The error terms on these estimates are large, and the range of uncertainty includes the possibility that the net effect is negligible. But on a 100-year basis, the net impact of $\mathrm{Nr}$ appears to be one of warming. Putting these estimates into a broader perspective, the modest warming effect US Nr shown in Fig. 1 is equivalent to less than $10 \%$ of the warming effect of US emissions of $\mathrm{CO}_{2}$ derived from fossil fuel combustion.

While the net radiative forcing from the alternation of the $\mathrm{N}$ cycle in the US may be relatively small, there are many offsetting impacts that occur over different 
time-scales. The long atmospheric half-life of $\mathrm{N}_{2} \mathrm{O}$ and uncertainties regarding the permanence of $\mathrm{C}$ sequestration mean that there is a risk that the longterm net warming effects may be underestimated. Moreover, the profound effect that excess $\mathrm{Nr}$ has on ecosystem processes and biodiversity suggests that assumptions about future radiative forcing of $\mathrm{C}-\mathrm{N}$ interactions played out in changing terrestrial and aquatic ecosystems must be considered with caution. Despite these uncertainties, we can conclude with confidence that $\mathrm{C}-\mathrm{N}$ interactions do have important climatic effects that should be included in future measurement and modeling efforts to improve understanding of biological feedbacks to climate change and global change processes.

\section{Research needs}

Improved quantification of the effects of excess $\mathrm{Nr}$ on radiative forcing will require improvements in our understanding of atmospheric chemical processes, rates of total $\mathrm{N}$ deposition, responses of ecosystems to $\mathrm{N}$ deposition, and integration of these processes into Earth system models. We identify a number of research needs below:

1. The complex nonlinear atmospheric chemistry involving $\mathrm{NO}, \mathrm{NO}_{2}, \mathrm{O}_{3}, \mathrm{OH}$, and $\mathrm{CH}_{4}$ and how it will change with climate and changing sources and sinks requires more research attention to determine impacts at times scales from days to decades.

2. The effects of the chemical composition of aerosols on radiative forcing and cloud formation are not well known.

3. Improvements are needed in spatially explicit modeling and measurements of all forms of $\mathrm{N}$ deposition. Estimates of deposition of organic-N are particularly uncertain.

4. Variation in $\mathrm{dC} / \mathrm{dN}$ responses of ecosystems and the factors that control them are poorly understood for both aboveground and belowground processes. Comparisons between model simulations and results from $\mathrm{N}$ addition enrichment studies, gradient analyses, and other field data are needed to validate and identify deficiencies in parameters of both empirical and process-based models.
5. Biogeochemical models need improvements to better constrain and reduce uncertainty of estimates of $\mathrm{N}$ losses associated with nitrification and denitrification, especially losses of $\mathrm{N}_{2}$ from denitrification.

6. Earth system models need improved representation of $\mathrm{C}-\mathrm{N}-\mathrm{P}$ interactions in ecosystems and their feedbacks to climate change. This includes feedbacks between vegetation, water vapor, and albedo. Most Earth system models also do not yet include the effects of anthropogenic $\mathrm{N}$ on radiative forcing mediated through changes in atmospheric chemistry.

Acknowledgments We thank several anonymous reviewers whose comments improved the quality of this manuscript. This work resulted from a workshop supported by NSF Research Coordination Network awards DEB-0443439 and DEB1049744 and by the David and Lucille Packard Foundation. Disclaimers: The material in this document has been subject to U.S. Environmental Protection Agency (EPA) technical and policy review, and approved for publication. The views expressed by individual authors; however, are their own and do not necessarily reflect those of EPA. Mention of trade names, products, or services does not convey, and should not be interpreted as conveying, official U.S. Environmental Protection Agency (EPA) approval, endorsement, or recommendation.

Open Access This article is distributed under the terms of the Creative Commons Attribution License which permits any use, distribution, and reproduction in any medium, provided the original author(s) and the source are credited.

\section{References}

Abbatt J, Benz S, Cziczo D, Kanji Z, Lohmann U, Möhler O (2006) Solid ammonium sulfate aerosols as ice nuclei: a pathway for cirrus cloud formation. Sci Agric 313:17701773

Aber J, McDowell W, Nadelhoffer K, Magill A, Berntson G, Kamakea M, McNulty S, Currie W, Rustad L, Fernandez I (1998) Nitrogen saturation in temperate forest ecosystems-hypotheses revisited. Biosci Biotechnol Biochem 48(11):921-934

Adams PJ, Seinfeld JH, Koch D, Mickley L, Jacob D (2001) General circulation model assessment of direct radiative forcing by the sulfate-nitrate-ammonium-water inorganic aerosol system. J Geophys Res 106(D1):1097-1111

Aerts R, Bobbink R (1999) The impact of atmospheric nitrogen deposition on vegetation processes in terrestrial non-forest ecosystems. Kluwer, Dordrecht, p. ix

Aerts R, Chapin FS (2000) The mineral nutrition of wild plants revisited: a re-evaluation of processes and patterns. Adv Ecol Res 30:1-67 
Aitkenhead JA, McDowell WH (2000) Soil C:N ratio as a predictor of annual riverine DOC flux at local and global scales. Glob Biogeochem Cycles 14(1):127-138

Appel K, Foley KM, Bash JO, Pinder RW, Dennis RL, Allen DJ, Pickering K (2010) A multi-resolution assessment of the community multiscale air quality (CMAQ) model v4.7 wet deposition estimates for 2002-2006. Geosci Model Dev 4:357-371

Bauer GA, Bazzaz FA, Minocha R, Long S, Magill A, Aber J, Berntson GM (2004) Effects of chronic N additions on tissue chemistry, photosynthetic capacity, and carbon sequestration potential of a red pine (Pinus resinosa Ait.) stand in the NE United States. For Ecol Manag 196(1): 173-186

Bauer SE, Koch D, Unger N, Metzger SM, Shindell DT, Streets DG (2007) Nitrate aerosols today and in 2030: a global simulation including aerosols and tropospheric ozone. Atmos Chem Phys 7(19):5043-5059

Berg B, Laskowski R (2006) Advances in ecological researchintroduction. Adv Ecol Res 38:1-17

Berg B, Matzner E (1997) Effect of N deposition on decomposition of plant litter and soil organic matter in forest systems. Environ Rev 5(1):1-25

Berntsen TK, Fuglestvedt JS, Joshi MM, Shine KP, Stuber N, Ponater M, Sausen R, Hauglustaine DA, Li L (2005) Response of climate to regional emissions of ozone precursors: sensitivities and warming potentials. Tellus B 57(4):283-304

Bloomer BJ, Stehr JW, Piety CA, Salawitch RJ, Dickerson RR (2009) Observed relationships of ozone air pollution with temperature and emissions. Geophys Res Lett 36(9):L09803

Bonan GB (2008) Forests and climate change: forcings, feedbacks, and the climate benefits of forests. Sci Agric 320(5882):1444-1449

Bonan GB, Levis S (2010) Quantifying carbon-nitrogen feedbacks in the Community Land Model (CLM4). Geophys Res Lett 37:6

Boucher O, Friedlingstein P, Collins B, Shine KP (2009) The indirect global warming potential and global temperature change potential due to methane oxidation. Environ Res Lett 4(4):044007

Bragazza L, Freeman C, Jones T, Rydin H, Limpens J, Fenner N, Ellis T, Gerdol R, Hajek M, Hajek T, Lacumin P, Kutnar L, Tahvanainen T, Toberman H (2006) Atmospheric nitrogen deposition promotes carbon loss from peat bogs. Proc Natl Acad Sci USA 103(51):19386-19389

Butterbach-Bahl K, Nemitz E, Zaehle S (2011) The European nitrogen assessment. Cambridge University Press, Cambridge

Carreiro MM, Sinsabaugh RL, Repert DA, Parkhurst DF (2000) Microbial enzyme shifts explain litter decay responses to simulated nitrogen deposition. Ecol Freshw Fish 81(9): 2359-2365

Clark CM, Tilman D (2008) Loss of plant species after chronic low-level nitrogen deposition to prairie grasslands. Nat Biotechnol 451(7179):712-715

Collins WJ, Sitch S, Boucher O (2010) How vegetation impacts affect climate metrics for ozone precursors. J Geophys Res 115(D23308). doi:10.1029/2010JD014187

Cusack DF, Silver WL, Torn MS, Burton SD, Firestone MK (2011) Changes in microbial community characteristics and soil organic matter with nitrogen additions in two tropical forest. Ecol Freshw Fish 92:621-632

Davidson EA (2009) The contribution of manure and fertilizer nitrogen to atmospheric nitrous oxide since 1860 . Nat Geosci 2(9):659-662

Davidson E, David M, Galloway J, Goodale C, Haeuber R, Harrison J, Howarth R, Jaynes D, Lowrance R, Nolan B, Peel J, Pinder R, Porter E, Snyder C, Townsend A, Ward M (2012) Excess nitrogen in the U.S. Environment: trends, risks, and solutions. ESA Issues Ecol 15:1-16

Del Grosso SJ, Parton WJ, Mosier AR, Ojima DS, Kulmala AE, Phongpan S (2000) General model for $\mathrm{N}_{2} \mathrm{O}$ and $\mathrm{N}_{2}$ gas emissions from soils due to dentrification. Glob Biogeochem Cycles 14(4):1045-1060

Denman K, Brasseur G, Chidthaisong A, Ciais P, Cox P, Dickinson RE, Haugustaine D, Heinze C, Holland E, Jacob D, Lohmann U, Ramachandran S, da Silva Dias P, SC W, Zhang X (2007) Couplings Between changes in the climate system and biogeochemistry. Cambridge University Press, Cambridge, pp 499-587

Derwent R, Stevenson D, Doherty R, Collins W, Sanderson M, Johnson C (2008) Radiative forcing from surface $\mathrm{NO}_{x}$ emissions: spatial and seasonal variations. Clim Change 88(3):385-401

Dijkstra FA, Hobbie SE, Knops JMH, Reich PB (2004) Nitrogen deposition and plant species interact to influence soil carbon stabilization. Ecol Lett 7(12):1192-1198

Elser JJ, Bracken ME, Cleland EE, Gruner DS, Harpole WS, Hillebrand H, Ngai JT, Seabloom EW, Shurin JB, Smith JE (2007) Global analysis of nitrogen and phosphorus limitation of primary producers in freshwater, marine and terrestrial ecosystems. Ecol Lett 10(12):1135-1142

Endresen O, Sorgard E, Sundet JK, Dalsoren SB, Isaksen ISA, Berglen TF, Gravir G (2003) Emission from international sea transportation and environmental impact. J Geophys Res 108(D17):22

Evans C, Goodale C, Caporn S, Dise N, Emmett B, Fernandez I, Field C, Findlay S, Lovett G, Meesenburg H, Moldan F, Sheppard L (2008) Does elevated nitrogen deposition or ecosystem recovery from acidification drive increased dissolved organic carbon loss from upland soil? A review of evidence from field nitrogen addition experiments. Biogeochemistry 91(1):13-35

Eyring V, Stevenson DS, Lauer A, Dentener FJ, Butler T, Collins WJ, Ellingsen K, Gauss M, Hauglustaine DA, Isaksen ISA, Lawrence MG, Richter A, Rodriguez JM, Sanderson M, Strahan SE, Sudo K, Szopa S, van Noije TPC, Wild O (2007) Multi-model simulations of the impact of international shipping on atmospheric chemistry and climate in 2000 and 2030. J Geophys Res 7:757-780

Felzer B, Kicklighter D, Melillo J, Wang C, Zhuang Q, Prinn R (2004) Effects of ozone on net primary production and carbon sequestration in the conterminous United States using a biogeochemistry model. Tellus B 56(3):230 248

Findlay SEG (2005) Increased carbon transport in the Hudson River: unexpected consequence of nitrogen deposition? Front Ecol Environ 3(3):133-137

Fiore AM, Jacob DJ, Field BD, Streets DG, Fernandes SD, Jang C (2002) Linking ozone pollution and climate change: the case for controlling methane. Geophys Res Lett 29:1919 
Fog K (1988) The effect of added nitrogen on the rate of decomposition of organic-matter. Biol Rev Camb Philos Soc 63(3):433-462

Forster P, Ramaswamy V, Artaxo P, Berntsen T, Betts R, Fahey DW, Haywood J, Lean J, Lowe D, Myhre G, Nganga J, Prinn R, Raga G, Schulz M, Van Dorland R (2007) Changes in atmospheric constituents and in radiative forcing. Cambridge University Press, Cambridge

Frey SD, Knorr M, Parrent JL, Simpson RT (2004) Chronic nitrogen enrichment affects the structure and function of the soil microbial community in temperate hardwood and pine forests. For Ecol Manag 196(1):159-171

Friedlingstein P, Cox P, Betts R, Bopp L, Von Bloh W, Brovkin V, Cadule P, Doney S, Eby M, Fung I, Bala G, John J, Jones C, Joos F, Kato T, Kawamiya M, Knorr W, Lindsay K, Matthews HD, Raddatz T, Rayner P, Reick C, Roeckner E, Schnitzler KG, Schnur R, Strassmann K, Weaver AJ, Yoshikawa C, Zeng N (2006) Climate-carbon cycle feedback analysis: results from the (CMIP)-M-4 model intercomparison. J Clim 19(14):3337-3353

Fry MM, Naik V, West JJ, Schwarzkopf MD, Fiore AM, Collins WJ, Dentener FJ, Shindell DT, Atherton C, Bergmann D, Duncan BN, Hess P, MacKenzie IA, Marmer E, Schultz MG, Szopa S, Wild O, Zeng G (2012) The influence of ozone precursor emissions from four world regions on tropospheric composition and radiative climate forcing. J Geophys Res 117(D7):D07306

Fuglestvedt J, Berntsen T, Myhre G, Rypdal K, Skeie RB (2008) Climate forcing from the transport sectors. Proc Natl Acad Sci USA 105(2):454-458

Fuglestvedt JS, Shine K, Berntsen T, Cook J, Lee D, Stenke A, Skeie R, Velders G, Waitz I (2010) Transport impacts on atmosphere and climate: metrics. Atmos Environ 44: 4648-4677

Galloway JN, Dentener FJ, Capone DG, Boyer EW, Howarth RW, Seitzinger SP, Asner GP, Cleveland CC, Green PA, Holland EA, Karl DM, Michaels AF, Porter JH, Townsend AR, Vorosmarty CJ (2004) Nitrogen cycles: past, present, and future. Biogeochemistry 70(2):153-226

Gassman P, Williams J, Wang X, Saleh A, Osei E, Hauck L, Izaurralde C, Flowers J (2009) The Agricultural Policy Environmental Extender (APEX) model: an emerging tool for landscape and watershed environmental analyses. Center for Agricultural and Rural Development (CARD) Publications, Ames

Gerber S, Hedin LO, Oppenheimer M, Pacala SW, Shevliakova E (2010) Nitrogen cycling and feedbacks in a global dynamic land model. Glob Biogeochem Cycles 24:15

Gower ST (2003) Patterns and mechanisms of the forest carbon cycle. Annu Rev Environ Resour 28:169-204

Hammel K (1997) Fungal degradation of lignin. CAB International, Wallingford, p xvi

Harpole WS, Ngai JT, Cleland EE, Seabloom EW, Borer ET, Bracken ME, Elser JJ, Gruner DS, Hillebrand H, Shurin JB, Smith JE (2011) Nutrient co-limitation of primary producer communities. Ecol Lett 14(9):852-862

Heath L, Smith J, Skog K, Nowak D, Woodall C (2011) Managed forest carbon estimates for the US greenhouse gas inventory, 1990-2008. J For 109:167-173
Hobbie SE (2005) Contrasting effects of substrate and fertilizer nitrogen on the early stages of litter decomposition. Ecosystems 8(6):644-656

Holland EA, Lamarque JF (1997) Modeling bio-atmospheric coupling of the nitrogen cycle through $\mathrm{NO}_{x}$ emissions and $\mathrm{NO}_{y}$ deposition. Nutr Cycling Agroecosyst 48(1-2):7-24

Holland EA, Braswell BH, Lamarque JF, Townsend A, Sulzman J, Muller JF, Dentener F, Brasseur G, Levy H, Penner JE, Roelofs GJ (1997) Variations in the predicted spatial distribution of atmospheric nitrogen deposition and their impact on carbon uptake by terrestrial ecosystems. J Geophys Res 102(D13):15849-15866

Hollinger DY, Ollinger SV, Richardson AD, Meyers TP, Dail DB, Martin ME, Scott NA, Arkebauer TJ, Baldocchi DD, Clark KL, Curtis PS, Davis KJ, Desai AR, Dragoni D, Goulden ML, Gu L, Katul GG, Pallardy SG, Paw U KT, Schmid HP, Stoy PC, Suyker AE, Verma SB (2010) Albedo estimates for land surface models and support for a new paradigm based on foliage nitrogen concentration. Glob Change Biol 16(2):696-710

Houlton BZ, Bai E (2009) Imprint of denitrifying bacteria on the global terrestrial biosphere. Proc Natl Acad Sci USA 106(51):21713-21716

Jacob DJ, Winner DA (2009) Effect of climate change on air quality. Atmos Environ 43(1):51-63

Jain A, Yang XJ, Kheshgi H, McGuire AD, Post W, Kicklighter D (2009) Nitrogen attenuation of terrestrial carbon cycle response to global environmental factors. Glob Biogeochem Cycles 23:13

Janssens IA, Dieleman W, Luyssaert S, Subke JA, Reichstein M, Ceulemans R, Ciais P, Dolman AJ, Grace J, Matteucci G, Papale D, Piao SL, Schulze ED, Tang J, Law BE (2010) Reduction of forest soil respiration in response to nitrogen deposition. Nat Geosci 3(5):315-322

Khler MO, Rdel G, Dessens O, Shine KP, Rogers HL, Wild O, Pyle JA (2008) Impact of perturbations to nitrogen oxide emissions from global aviation. J Geophys Res 113(D11): D11305

Knorr M, Frey SD, Curtis PS (2005) Nitrogen additions and litter decomposition: a meta-analysis. Ecol Freshw Fish 86(12):3252-3257

LaFranchi BW, Goldstein AH, Cohen RC (2011) Observations of the temperature dependent response of ozone to $\mathrm{NO}_{x}$ reductions in the Sacramento, CA urban plume. Atmos Chem Phys 11(14):6945-6960

Lamarque JF, McConnell JR, Shindell DT, Orlando JJ, Tyndall GS (2011) Understanding the drivers for the 20th century change of hydrogen peroxide in antarctic ice-cores. Geophys Res Lett 38:5

LeBauer DS, Treseder KK (2008) Nitrogen limitation of net primary productivity in terrestrial ecosystems is globally distributed. Ecol Freshw Fish 89(2):371-379

Li CS, Aber J, Stange F, Butterbach-Bahl K, Papen H (2000) A process-oriented model of $\mathrm{N}_{2} \mathrm{O}$ and $\mathrm{NO}$ emissions from forest soils: 1. Model development. J Geophys Res 105(D4): 4369-4384

Liao H, Seinfeld JH (2005) Global impacts of gas-phase chemistry-aerosol interactions on direct radiative forcing by anthropogenic aerosols and ozone. J Geophys Res 110(D18):D18,208 
Liu LL, Greaver TL (2009) A review of nitrogen enrichment effects on three biogenic GHGs: the $\mathrm{CO}_{2}$ sink may be largely offset by stimulated $\mathrm{N}_{2} \mathrm{O}$ and $\mathrm{CH}_{4}$ emission. Ecol Lett 12(10):1103-1117

Liu LL, Greaver TL (2010) A global perspective on belowground carbon dynamics under nitrogen enrichment. Ecol Lett 13(7):819-828

Luyssaert S, Inglima I, Jung M, Richardson AD, Reichstein M, Papale D, Piao SL, Schulze ED, Wingate L, Matteucci G, Aragao L, Aubinet M, Beer C, Bernhofer C, Black KG, Bonal D, Bonnefond JM, Chambers J, Ciais P, Cook B, Davis KJ, Dolman AJ, Gielen B, Goulden M, Grace J, Granier A, Grelle A, Griffis T, GrNwald T, Guidolotti G, Hanson PJ, Harding R, Hollinger DY, Hutyra LR, Kolari P, Kruijt B, Kutsch W, Lagergren F, Laurila T, Law BE, Le Maire G, Lindroth A, Loustau D, Malhi Y, Mateus J, Migliavacca M, Misson L, Montagnani L, Moncrieff J, Moors E, Munger JW, Nikinmaa E, Ollinger SV, Pita G, Rebmann C, Roupsard O, Saigusa N, Sanz MJ, Seufert G, Sierra C, Smith ML, Tang J, Valentini R, Vesala T, Janssens IA (2007) $\mathrm{CO}_{2}$ balance of boreal, temperate, and tropical forests derived from a global database. Glob Change Biol 13(12):2509-2537

Mack MC, Schuur EAG, Bret-Harte MS, Shaver GR, Chapin FS (2004) Ecosystem carbon storage in arctic tundra reduced by long-term nutrient fertilization. Nat Biotechnol 431(7007): $440-443$

Magnani F, Mencuccini M, Borghetti M, Berbigier P, Berninger F, Delzon S, Grelle A, Hari P, Jarvis PG, Kolari P, Kowalski AS, Lankreijer H, Law BE, Lindroth A, Loustau D, Manca G, Moncrieff JB, Rayment M, Tedeschi V, Valentini R, Grace J (2007) The human footprint in the carbon cycle of temperate and boreal forests. Nat Biotechnol 447(7146):848-850

Martin ST, Hung HM, Park RJ, Jacob DJ, Spurr RJD, Chance KV, Chin M (2004) Effects of the physical state of tropospheric ammonium-sulfate-nitrate particles on global aerosol direct radiative forcing. Atmos Chem Phys 4:183-214

Melillo JM, McGuire AD, Kicklighter DW, Moore B, Vorosmarty CJ, Schloss AL (1993) Global climate-change and terrestrial net primary production. Nat Biotechnol 363(6426): 234-240

Melillo JM, Reilly JM, Kicklighter DW, Gurgel AC, Cronin TW, Paltsev S, Felzer BS, Wang XD, Sokolov AP, Schlosser CA (2009) Indirect emissions from biofuels: how important? Sci Agric 326(5958):1397-1399

Melillo JM, Butler S, Johnson J, Mohan J, Steudler P, Lux H, Burrows E, Bowles F, Smith R, Scott L, Vario C, Hill T, Burton A, Zhou YM, Tang J (2011) Soil warming, carbonnitrogen interactions, and forest carbon budgets. Proc Natl Acad Sci USA 108(23):9508-9512

Metcalfe DB, Fisher RA, Wardle DA (2011) Plant communities as drivers of soil respiration: pathways, mechanisms, and significance for global change. Biogeosciences 8(8):2047-2061

Monteith DT, Stoddard JL, Evans CD, de Wit HA, Forsius M, Hogasen T, Wilander A, Skjelkvale BL, Jeffries DS, Vuorenmaa J, Keller B, Kopacek J, Vesely J (2007) Dissolved organic carbon trends resulting from changes in atmospheric deposition chemistry. Nat Biotechnol 450(7169):537-540

Mosier A, Schimel D, Valentine D, Bronson K, Parton W (1991) Methane and nitrous oxide fluxes in native, fertilized and cultivated grasslands. Nat Biotechnol 350:330-332
Myhre G, Berglen TF, Johnsrud M, Hoyle CR, Berntsen TK, Christopher SA, Fahey DW, Isaksen ISA, Jones TA, Kahn RA, Loeb N, Quinn P, Remer L, Schwarz JP, Yttri KE (2009) Modelled radiative forcing of the direct aerosol effect with multi-observation evaluation. Atmos Chem Phys 9(4):1365-1392

Nadelhoffer KJ, Emmett BA, Gundersen P, Kjonaas OJ, Koopmans CJ, Schleppi P, Tietema A, Wright RF (1999) Nitrogen deposition makes a minor contribution to carbon sequestration in temperate forests. Nat Biotechnol 398(6723): $145-148$

Nadelhoffer KJ, Colman BP, Currie WS, Magill A, Aber JD (2004) Decadal-scale fates of N-15 tracers added to oak and pine stands under ambient and elevated $\mathrm{N}$ inputs at the Harvard Forest (USA). For Ecol Manag 196(1):89-107

Naik V, Mauzerall D, Horowitz L, Schwarzkopf MD, Ramaswamy V, Oppenheimer M (2005) Net radiative forcing due to changes in regional emissions of tropospheric ozone precursors. J Geophys Res 110(D24):D24306

Nave LE, Vance ED, Swanston CW, Curtis PS (2009) Impacts of elevated $\mathrm{N}$ inputs on north temperate forest soil $\mathrm{C}$ storage, $\mathrm{C} / \mathrm{N}$, and net $\mathrm{N}$-mineralization. Geoderma 153(1-2): 231-240

Nemergut DR, Townsend AR, Sattin SR, Freeman KR, Fierer N, Neff JC, Bowman WD, Schadt CW, Weintraub MN, Schmidt SK (2008) The effects of chronic nitrogen fertilization on alpine tundra soil microbial communities: implications for carbon and nitrogen cycling. Environ Microbiol 10(11):3093-3105

Olander LP, Haugen-Kozyra K (2011) Using biogeochemical process models to quantify greenhouse gas mitigation from agricultural management projects: Technical working group on agricultural greenhouse gases. Tech. Rep. Report NI R 11-03, Duke University Nicholas Institute for Environmental Policy Solutions

Ollinger SV, Aber JD, Reich PB (1997) Simulating ozone effects on forest productivity: interactions among leaf-, canopy-, and stand-level processes. Ecol Appl 7(4):1237-1251

Ollinger SV, Richardson AD, Martin ME, Hollinger DY, Frolking SE, Reich PB, Plourde LC, Katul GG, Munger JW, Oren R, Smithb ML, U KTP, Bolstad PV, Cook BD, Day MC, Martin TA, Monson RK, Schmid HP (2008) Canopy nitrogen, carbon assimilation, and albedo in temperate and boreal forests: functional relations and potential climate feedbacks. Proc Natl Acad Sci USA 105(49):19336-19341

Pardo LH, Fenn ME, Goodale CL, Geiser LH, Driscoll CT, Allen EB, Baron JS, Bobbink R, Bowman WD, Clark CM, Emmett B, Gilliam FS, Greaver TL, Hall SJ, Lilleskov EA, Liu L, Lynch JA, Nadelhoffer KJ, Perakis SS, RobinAbbott MJ, Stoddard JL, Weathers KC, Dennis RL (2011) Effects of nitrogen deposition and empirical nitrogen critical loads for ecoregions of the united states. Ecol Appl 21(8):3049-3082

Pastor J, Post WM (1988) Response of northern forests to $\mathrm{CO}_{2}$ induced climate change. Nat Biotechnol 334(6177):55-58

Penner JE, Prather MJ, Isaksen ISA, Fuglestvedt JS, Klimont Z, Stevenson DS (2010) Short-lived uncertainty? Nat Geosci 3(9):587-588

Pinder R, Davidson E, Goodale C, Greaver T, Herrick J, Liu L (2012) Climate change impacts of US reactive nitrogen. Proc Natl Acad Sci USA 109(20):7671-7675 
Ramirez K, Lauber C, Knight R, Bradford M, Fierer N (2010) Consistent effects of nitrogen fertilization on soil bacterial communities in contrasting systems. Ecol Freshw Fish 9:3463-3470

Ryan MG, Binkley D, Fownes JH, Giardina CP, Senock RS (2004) An experimental test of the causes of forest growth decline with stand age. Ecol Monogr 74(3):393-414

Saiya-Cork KR, Sinsabaugh RL, Zak DR (2002) The effects of long term nitrogen deposition on extracellular enzyme activity in an Acer saccharum forest soil. Soil Biol Biochem 34(9):1309-1315

Schlesinger WH (2009) On the fate of anthropogenic nitrogen. Proc Natl Acad Sci USA 106(1):203-208

Schlesinger WH (2010) On fertilizer-induced soil carbon sequestration in chinas croplands. Glob Change Biol 16(2):849-850

Schlesinger WH, Cole J, Finzi A, Holland E (2011) Introduction to coupled biogeochemical cycles. Front Ecol Environ 9(1):5-8

Shindell D, Faluvegi G, Koch D, Schmidt G, Unger N, Bauer S (2009) Improved attribution of climate forcing to emissions. Sci Agric 326:716-718

Sinsabaugh RL, Moorhead DL (1994) Resource allocation to extracellular enzyme production: a model for nitrogen and phosphorus control of litter decomposition. Soil Biol Biochem 26:1305-1311

Sinsabaugh RL, Carreiro MM, Repert DA (2002) Allocation of extracellular enzymatic activity in relation to litter composition, $\mathrm{N}$ deposition, and mass loss. Biogeochemistry 60(1): $1-24$

Sinsabaugh RL, Zak DR, Gallo M, Lauber C, Amonette R (2004) Nitrogen deposition and dissolved organic carbon production in northern temperate forests. Soil Biol Biochem 36(9):1509-1515

Sitch S, Cox PM, Collins WJ, Huntingford C (2007) Indirect radiative forcing of climate change through ozone effects on the land-carbon sink. Nat Biotechnol 448(7155): 791-794

Sokolov AP, Kicklighter DW, Melillo JM, Felzer BS, Schlosser CA, Cronin TW (2008) Consequences of considering carbon-nitrogen interactions on the feedbacks between climate and the terrestrial carbon cycle. J Clim 21(15): 3776-3796

Sorooshian A, Murphy SM, Hersey S, Gates H, Padro LT, Nenes A, Brechtel FJ, Jonsson H, Flagan RC, Seinfeld JH (2008) Comprehensive airborne characterization of aerosol from a major bovine source. Atmos Chem Phys 8:5489-5520, doi: 10.5194/acp-8-5489-2008

Stevenson DS, Doherty RM, Sanderson MG, Collins WJ, Johnson CE, Derwent RG (2004) Radiative forcing from aircraft $\mathrm{NO}_{\mathrm{x}}$ emissions: mechanisms and seasonal dependence. J Geophys Res 109(D17):D17307

Sutton MA, Simpson D, Levy PE, Smith RI, Reis S, van Oijen M, de Vries W (2008) Uncertainties in the relationship between atmospheric nitrogen deposition and forest carbon sequestration. Glob Change Biol 14(9):2057-2063

Syakila A, Kroeze C (2011) The global nitrous oxide budget revisited. Greenh Gas Meas Manag 1:17-26

Thomas RQ, Canham CD, Weathers KC, Goodale CL (2010) Increased tree carbon storage in response to nitrogen deposition in the US. Nat Geosci 3(1):13-17
Thornton PE, Doney SC, Lindsay K, Moore JK, Mahowald N, Randerson JT, Fung I, Lamarque JF, Feddema JJ, Lee YH (2009) Carbon-nitrogen interactions regulate climate-carbon cycle feedbacks: results from an atmosphere-ocean general circulation model. Biogeosciences 6(10):2099-2120

Townsend AR, Vitousek PM, Desmarais DJ, Tharpe A (1997) Soil carbon pool structure and temperature sensitivity inferred using $\mathrm{CO}_{2}$ and (13) $\mathrm{CO}_{2}$ incubation fluxes from five Hawaiian soils. Biogeochemistry 38(1):1-17

Treseder KK (2004) A meta-analysis of mycorrhizal responses to nitrogen, phosphorus, and atmospheric $\mathrm{CO}_{2}$ in field studies. New Phytol 164(2):347-355

United States Environmental Protection Agency Office of Atmospheric Programs (2011) Inventory of U.S. greenhouse gas emissions and sinks: 1990-2009, USEPA Report Number 430-R-11-005. USEPA, Office of Atmospheric Programs, Washington

Van Groenigen KJ, Osenberg CW, Hungate BA (2011) Increased soil emissions of potent greenhouse gases under increased atmospheric $\mathrm{CO}_{2}$. Nat Biotechnol 475(7355): 214-216

Waldrop MP, Zak DR, Sinsabaugh RL, Gallo M, Lauber C (2004) Nitrogen deposition modifies soil carbon storage through changes in microbial enzymatic activity. Ecol Appl 14(4):1172-1177

Wang YP, Law RM, Pak B (2010) A global model of carbon, nitrogen and phosphorus cycles for the terrestrial biosphere. Biogeosciences 7(7):2261-2282

West JJ, Fiore AM, Naik V, Horowitz LW, Schwarzkopf MD, Mauzerall DL (2007) Ozone air quality and radiative forcing consequences of changes in ozone precursor emissions. Geophys Res Lett 34(6):L06806

Wild O, Prather MJ, Akimoto H (2001) Indirect long-term global radiative cooling from $\mathrm{NO}_{x}$ Emissions. Geophys Res Lett 28(9):1719-1722

Williams J, Nearing M, Nicks A, Skidmore E, Valentin C, King K, Savabi R (1996) Using soil erosion models for global change studies. J Soil Water Conserv 51(5):381-385

Xia JY, Wan SQ (2008) Global response patterns of terrestrial plant species to nitrogen addition. New Phytol 179(2): 428-439

$\mathrm{Xu} \mathrm{L}$, Penner JE (2012) Global simulations of nitrate and ammonium aerosols and their radiative effects. Atmos Chem Phys Discuss 12(4):10,115-10,179

Yang XJ, Wittig V, Jain AK, Post W (2009) Integration of nitrogen cycle dynamics into the integrated science assessment model for the study of terrestrial ecosystem responses to global change. Glob Biogeochem Cycles 23:18

Zaehle S, Friend AD, Friedlingstein P, Dentener F, Peylin P, Schulz M (2010) Carbon and nitrogen cycle dynamics in the O-CN land surface model: 2. Role of the nitrogen cycle in the historical terrestrial carbon balance. Glob Biogeochem Cycles 24:14

Zaehle S, Ciais P, Friend A, Prieur V (2011) Carbon benefits of anthropogenic reactive nitrogen offset by nitrous oxide emissions. Nat Geosci 4:601-605

Zhuang Q, Lu Y, Chen M (2012) An inventory of global $\mathrm{N}_{2} \mathrm{O}$ emissions from the soils of natural terrestrial ecosystems. Atmos Environ 47:68-75 